\title{
INTEGRATION OF CONTENT AND LANGUAGE INTEGRATED LEARNING ELEMENTS IN THE EDUCATION OF NONLINGUISTIC SPECIALTY STUDENTS BY MEANS OF INFORMATION TECHNOLOGIES
}

\author{
Anna Kotova \\ V. N. Karazin National University, Ukraine \\ Victorya Serdyuk \\ V. N. Karazin National University, Ukraine \\ Iryna Avdieienko \\ V. N. Karazin National University, Ukraine \\ Olena Lenska \\ V. N. Karazin National University, Ukraine \\ Orina Ivaniga \\ Semen Kuznets Kharkiv National University of Economics, Ukraine
}

\begin{abstract}
The article deals with the problem of CLIL elements integration when teaching students of non-linguistic specialities. Main approaches to the definition of this teaching method are given. It is found that different authors consider CLIL as an educational approach, special education techniques, flexible curricular etc., the main purpose of CLIL methodology is to create the link between the study of the foreign language and the content of the students' major discipline. The necessity of the IT implementation into the educational process has been substantiated (it allows to reduce the unproductive costs of the teacher's labour, gives students wide scope to a freely choose their own trajectory, increases the efficiency and objectivity of monitoring and evaluating learning outcomes, promotes individualization of educational activities, etc.).

We have to use IT technologies as they help improve and diversify students' work. Precisely, when working with students we often use Moodle platform as it provides unlimited opportunities for both students and teachers. It is found that Moodle platform allows developing reading, listening, writing, and grammar skills. Some examples of how to work using Moodle platform is given in the article. It is shown that such parts of Moodle platform as Chat and Forum are of great interest for both foreign language teachers and students. For those students who officially work or are ill, the Assignment module is of particular interest.
\end{abstract}

Keywords: non-linguistic students; CLIL; information technologies; Moodle. 
Kotova et al., 2021. Integration of Content and Language Integrated Learning Elements in the Education of Nonlinguistic Specialty Students by Means of Information Technologies

\section{Introduction}

Learning a foreign language is a necessary element of the future specialists' formation in any field of science and human activity. This is due to the processes of globalization and European integration of Ukraine. Those who speak English fluently, have the opportunity to be acquainted with the latest developments of the science they specialize in, share experience with colleagues from other regions and countries, participate in international conferences without a language barrier, etc.

Nowadays, practice has proved that teaching English based only on texts on specialty and exercises aimed at the remembering lexical units and grammar constructions, is not relevant any more. On the one hand, this is due to the informatization of society, and on the other hand, it is linked to the change in the mentality of young people who spend most of their time in the virtual world. As it is known, students find most information on the Internet, but not in print media. Thus, we have to meet modern requirements and take appropriate steps when teaching a foreign language.

One of the effective ways to solve this problem is the integration of CLIL (Content and Language Integrated Learning) elements using IT in the pedagogic process. Such an approach allows studying non-core disciplines and deepen their professional knowledge at the same time. Within the framework of the CLIL methodology, students gain proficiency in lexical units and learn to use appropriate grammatical constructions in professional communication, which allows them to prepare them for participation in academic mobility projects and for participation in international conferences, the working language of which is English.

We should also empathize that the introduction of CLIL elements in the educational process is rather teamwork, which requires creative approaches, discussions and sharing experience. Thus, the article represents the approaches of the authors who work with students of different specialties.

Literature review has shown that CLIL has been used as a method of the foreign language teaching for a long time. Its founder is David Marsh who used this method to teach the French language in Canada and North America in the mid-1960s (D. Marsh \& T. Nikula, 1998). Over time, this teaching technique began to attract more attention from scientists all over the world. In particular, the theoretical aspects of CLIL are discussed in the works by D. Coyle, P. Ball, D. Lindsay, and D. Marsh (the history of the formation of this pedagogical problem, its pedagogical significance and definition); Ch. Dalton-Puffer and D. Marsh (Discourse in Content and Language Integrated Learning Classrooms); M. Long (Focus on form: A design feature in language teaching methodology); T. Nikula (Terminological Considerations for Content and Language Integrated Learning), 
Atkinson D. (Sociocognitive Approach to Second Language Acquisition), etc. Such researchers as V. Malanin, S. Suslov, B. Polyanin, A. Kokareva, M. Zvereva, O. Vyshtak and many others have investigated the problem of IT in the educational process.

At the same time, deeply appreciating the contribution of scientists to the development of this scientific problem, we believe that the pedagogical literature does not sufficiently cover the practical methods of CLIL integration in the teaching process.

Therefore, the purpose of our publication is to share the experience of integration of CLIL elements in the educational process of non-linguistic specialties students during English language classes by means of information technologies, as modern society requires the implementation of IT in the educational process.

For this we consider it necessary to solve the following tasks:

1. generalize CLIL theoretical issues;

2. outline the role of IT in the educational process;

3. share some pedagogical experience on this issue.

\section{Methodology}

The methodological basis for writing our article is the methodological works of Coyle, Hood, \& Marsh (2010), Llinares \& Whttaker (2006), etc. During the work on the article, the methods of critical analysis of scientific literature, the method of systematizing and generalizing the approaches how to work with students of non-linguistic faculties were used. These approaches helped to identify the priority of CLIL methods for working with students in non-linguistic specialties.

\section{Research Results Theoretical Background}

On the basis of the analyses of pedagogical literature we can state that there are different approaches to CLIL definitions. It is considered as:

- a pedagogic approach and learning tool which create the connection between the content and language in the form of a case or a project. Such an approach does not require the use of another language to give instructions (Coyle, Hood, \& Marsh (2010);

- $\quad$ special academic techniques used during workshops to facilitate the process of a foreign language acquisition (Ball \& Lindsay, 2010; Llinares \& Whttaker (2006); 
- a methodological approach, based on (special) professional knowledge (Marsch et al, 1998; Content and Language Integrated Learning at School in Europe [CLILSE], 2006);

- $\quad$ flexible curricular design and timetable organization which are ranged from early total, early partial, and late immersion type programs, to modular subject-determined slots (Beadsmore, 2008);

- the mix of the theoretical grounds of constructivism and foreign language learning (Marsh \& Frigols, 2013);

- means of foreign language studying, which combines the content of learning, communication, cognition, and culture (Language competences for employability, mobility and growth [LCEMG], 2012).

Thus, summing up the approaches to the CLIL definitions, we can conclude that CLIL is a flexible teaching method which combines the acquisition of knowledge on specialty and the study of a foreign language.

CLIL can be implemented during classes with both students who are fluent in the language at the A2 level and with individuals who are fluent in the language at a higher level. An important part of CLIL methods is scaffolding, which is a special type of instructional process that takes place in situations where the teacher and learners interact to solve learning problems. The main characteristic of the scaffolding strategy is "fading help" from the teacher. As it is stated in Content and Language Integrated Learning at School in Europe (2006) and Language competences for employability, mobility and growth" (2012), "fading help" from the teacher at the beginning of training can be frequent and meaningful, and by the end of the course, it is significantly reduced or absent altogether.

The analysis of pedagogical literature also proved that CLIL:

- $\quad$ creates conditions for a naturalistic approach to language learning;

- $\quad$ encourages active communication in English during classes;

- creates positive motivation for learning English focusing on content, rather than on the form of expression;

- $\quad$ allows acquiring new knowledge and skills;

- $\quad$ stimulates mental processes which are responsible for the development of skills which connecting concrete and abstract concepts;

- $\quad$ teaches students to compare alternative points of view and views on concepts and events (Ball et al. 2010; CLILSE, 2006; Dalton-Puffer \& D. Marsh, 2007).

P. Lightbown and V. Spada emphasize the fact that the second language (in our case English) is better acquired if the conditions for its usage are similar to their mother tongue and express the similar view. In other words, the emphasis in the provision of instructions to learning shifts from the form of expression to its 
content. Scientists emphasize that students will be more effective if they learn a foreign language not by performing various exercises and reading texts on speciality, but rather when communicating with other students (Lightbown \& Spada, 1997).

\section{Role of IT in the Educational Process}

The use of modern information technologies in the educational process makes it possible to improve the quality of education and enhance the educational effects from the use of innovative pedagogical programs and methods, since it gives teachers additional opportunities for building individual educational trajectories of students. The use of information technology makes it possible to implement a differentiated approach to students with different levels of readiness for learning.

The training system using information technology has a number of advantages:

- $\quad$ allows to reduce the unproductive labour costs of the teacher;

- $\quad$ gives students wide scope to a freely choose their own trajectory of learning in the process of acquiring knowledge;

- $\quad$ supposes a differential approach to students, based on the recognition of the fact that they may have different previous experience and level of knowledge in the studied areas of knowledge, each student comes to the process of mastering new knowledge with his own intellectual baggage, which determines the degree of understanding of them new material and its interpretation;

- increases the efficiency and objectivity of monitoring and evaluation of learning outcomes;

- guarantees continuous communication in the relationship "studentteacher";

- $\quad$ promotes the individualization of learning activities (differentiation of the pace of learning, the severity of learning tasks, etc.) (Kulik, 2019).

Regarding the use of IT technologies in foreign language classes teachers state that IT help:

- $\quad$ form students' reading skills;

- $\quad$ improve listening and writing skills;

- $\quad$ enrich students' vocabulary;

- improve knowledge of grammar;

- find out a lot of new interesting and up-to-date information about the culture of the country, its traditions etc. (Kotova, 2015; Ovtcharenko, 2018; Borova, 2013; Long, 1991). 
Today there are many interesting and useful sites and platforms that promote the study of a foreign language, but the Moodle system is the most popular among higher educational institutions. According to the information located on the world site in the Moodle system, as of January 2018, 65,000,000 users, 6,000,000 courses and 64,000 sites were registered in 233 countries around the world.

Moodle's popularity can be attributed to its focus on collaboration. The system provides a lot of tools for this: wiki, glossary, blogs, forums, workshops. At the same time, training can be carried out both asynchronously, when each student studies the material at his own pace, and in real time, organizing online lectures, webinars and seminars. Moodle also provides ample opportunities for the use of multimedia in the system, the use of which significantly increases the effectiveness of teaching and the interest of students in learning new material (Kolos, 2011).

\section{Findings}

Teaching English to students of non-linguistic specialties differs from training foreign-language department students. The main task of classes of ESP (English for Specific Purposes) is to unite English as a subject with information on specialty. Our pedagogical experience has shown that Moodle is one of the best options to solve these tasks, as it provides unlimited possibilities for both teachers and students to create qualitative, dynamic, logical and structured courses and tasks for students' independent work. One important thing is that when working with Moodle, its users do not need any special programming skills, they can create a learning environment following the instructions on this educational platform. Moodle provides great opportunities to develop reading, writing, and listening skills of students. Working with Moodle students can choose convenient time and place to perform the tasks given (Petruk, 2011; Forostiuk, 2017; Lukianenko, 2014).

There are several opportunities for English teachers when working in Moodle. They can add several interactive elements to the platform, creating various kinds of activities (Nergiz Kern, 2013) and combining the acquisition of special knowledge with the learning of the foreign language, which is the core idea of CLIL (Coyle, 2010). For example, working with students who specialize in microbiology we ask them to read and translate the text on the specialty using Moodle as a home task. For this we download (or give a link to) the text on specialty and do special assignments on the platform. At the end of the text, we give them several questions on the topic or create tests in the quiz section. These activities allow saving time for checking homework, as the results are displayed on the monitor of the computer, and the teacher can see who accomplished the task. Besides, students can be directed to other useful resources including video, 
audio or texts which can be very helpful as material for presentations and supplementary resources on the topic.

In addition to texts and lectures, the teacher can add different drawings or illustrations to the chat, which motivates students to use creative thinking, and thus we encourage the students to study the topic. From the perspective of CLIL methods, it helps not only improve English writing skills and vocabulary, but allows mixing some theoretical concepts of the students' major and foreign language learning (Marsh \& Frigols, 2013).

For example, working on the topic of "History of Microbiology", "Morphology and System of Microorganisms", "Physiology of Microorganisms" we invite students to join Forum and Chat where both the students and the teacher can share information by writing comments. From the point of view of CLIL methodology such a technique can be considered as a way to compare alternative points of view and views on concepts and events (Ball et al. 2010; Dalton-Puffer \& Marsh, 2007).

Similar tasks and techniques are used when working with students of Schools of Physics. For example, Moodle course for Physicists includes the following topics:

- $\quad$ Nuclear energy. Harms and Benefits;

- $\quad$ Structure of Atoms;

- Different Branches of Physics. What to Choose to be Successful.

In order to implement CLIL elements we suggest students to read and translate a text on specialty. Such texts include some mistakes that they have to find and correct. Mistakes can be of different nature (grammar, spelling or specialty competence) depending on the level of students' knowledge. Doing this task, students share their comments and reasons (speaking about mistakes on special knowledge) in such sections of Moodle as Forum or Chat. To prove their point of view they can give a link to an English site, an article, a video, a book, etc.

Another technique to combine how to learn major and English is to download some photos of famous physicists (Marie Curie, A. Becquerel, A. Compton, and others) and ask students to write comments on their research and findings. This task helps practice writing skills and vocabulary, and on the other hand familiarizes students with the greatest scientific achievements, because, as practice has shown, not all students are aware of the evolution of a specific science even if it is their major.

The structure of the topic "Nuclear Energy. Harms and benefits" is represented in Figure 1. 
Kotova et al., 2021. Integration of Content and Language Integrated Learning Elements in the Education of Nonlinguistic Specialty Students by Means of Information Technologies

Figure 1 The structure of the topic "Nuclear Energy. Harms and benefits"

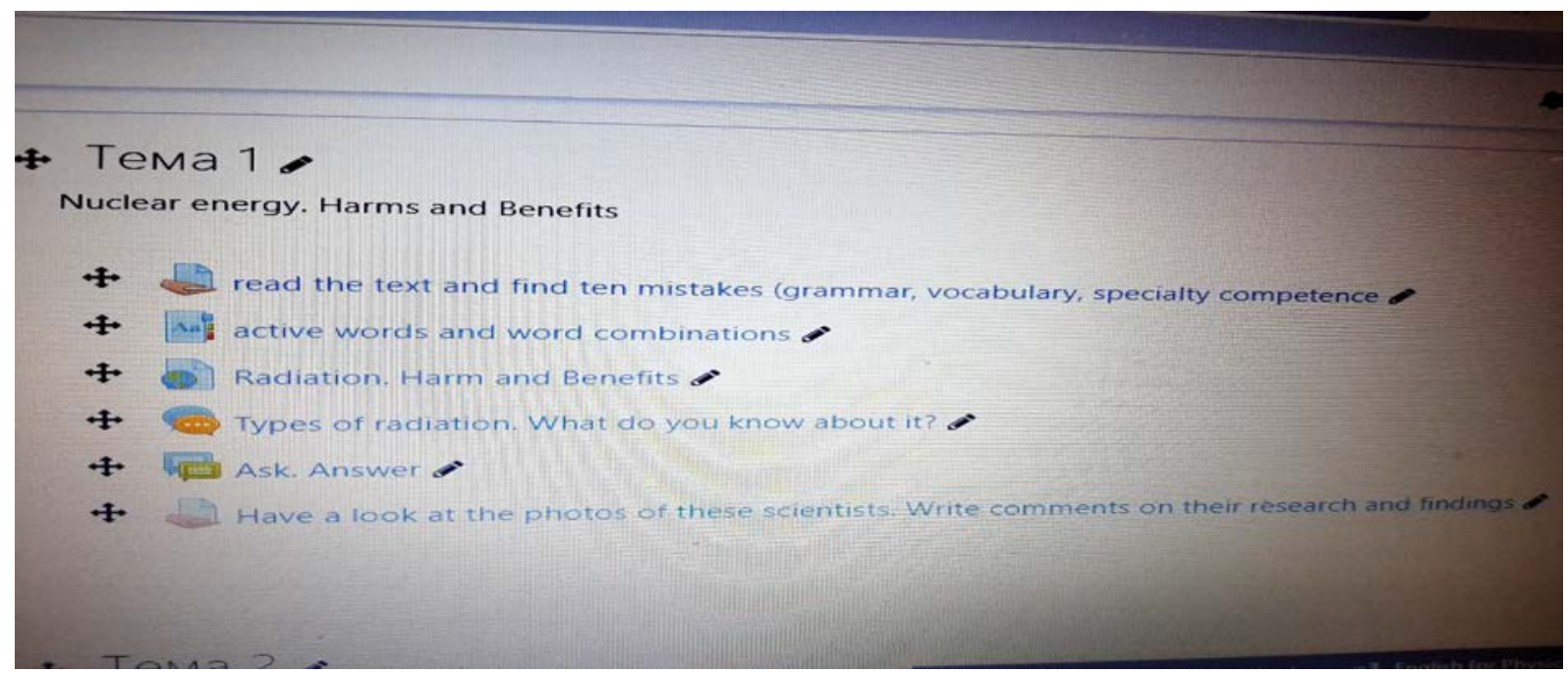

To accomplish each topic students are given two weeks. They have to read the text and do some exercises, watch a video and write a comment on it, write a short essay on the topic and respond to other students' ideas (agree or disagree, and explain why).

It is important to mention that such activities as finding grammar mistakes, writing essays and making presentations are considered to be scaffolding activities, as students are encouraged to work independently, on the ground of the vocabulary and grammar constructions in the texts, which were read and translated with the help of the teacher.

From our point of view, the fulfilment of such tasks on the one hand allows plunging into professional knowledge, and on the other hand, improve English language skills. At the same time, it should be noted that for the effective organization of educational activities, it is advisable to coordinate the topics with the work programs of the main disciplines and study these topics in parallel with them.

To create conditions for a naturalistic approach to language learning, stimulates active communication in English during classes and encourage students to acquire new knowledge and skills.

In chat, we organize the discussion on the topic, which is studied. Creating and downloading tasks, we should bear in mind that there are four types of Forum, which you can use depending on your purpose:

- $\quad$ standard Forum for general use;

- $\quad$ general discussion of a matter;

- discussion for every participant;

- question-answer. 
Along with Forum, we use Chat as a very convenient tool for guidance, where the teacher and the student can communicate online with each other. The Chat can be controlled by the teacher and, in order to use it online, the teacher and the student determine in advance the specific time and the Chat participants must $\log$ in to Moodle at the exact time. In order for Chat to work efficiently, the teacher has to limit the number of participants to $6-8$, and then all students are guaranteed participation. The advantage of Chat is that the students receive answers immediately. During such an activity we discuss some grammar topics, prepare for group presentations or reports.

Speaking about Moodle, we should mention Assignment module which can be very useful for the students who are absent from classes for one reason or another. By means of this module students can accomplish tasks and send them in the form of electronic document through the Moodle. Only the teacher can see these documents. If the task is given in the form of the test, the teacher, without leaving the Moodle system, can check, correct and make comments. This module is also interesting for shy students who are not ready to make presentations in class. This platform is also used for the training of listening skills, as Moodle has the opportunity to download audio and video materials on the specialty. Different tests can be created for checking students' progress. There is an option to limit time of test performance by students if necessary.

Moodle has gained even more significance since the spring of 2020, when the quarantine was announced. Teachers had to reconsider their educational methods and look for the development of e-learning.

\section{Conclusions}

Summing up, we shall note that CLIL is an effective teaching method for students of non-language faculties, with the help of which applicants for education have the opportunity to review the educational material that is studied during core disciplines and learn English. The use of information technologies, in particular Moodle, makes the learning process even more effective, because e-learning opens up a wide range of opportunities for each student and his/her academic achievements; helps teachers facilitate the control of students' performance and intensify the educational process. It is also very important that such a type of learning increases students' motivation to learn the subject. Moodle is an effective tool to improve reading, writing, and grammar skills; it also helps teachers and students to be in touch, being an interactive means of communication. This allows the teacher to give some classes to students not only during the class time, but also extracurricular, as well as to evaluate students' knowledge at any time.

However, on the other hand, we believe that despite all the advantages of using this platform in order to organize an effective learning process, these 
Kotova et al., 2021. Integration of Content and Language Integrated Learning Elements in the Education of Nonlinguistic Specialty Students by Means of Information Technologies

methods should rather be an addition to the classical methods of teaching a foreign language.

\section{References}

Ball, P., Lindsay, D. (2010). Teacher Training for CLIL in the Basque Country: The Case of the Ikastolas -An Expediency Model. An Expediency Model, 162-188.

Beadsmore, H. (2008). Multilingual Education, Cognition and Creativity. International CLIL Research Journal, V. 1(1), 7-16.

Borova, T. (2013) Innivative Information Technologies in the Educational Process of ESP for University Students. Traditsii I Novatsii Suchasnoy Osviti v Ukraini, № 3, $25-28$.

Coyle, D., Hood, P., Marsh, D. (2010). Content and Language Integrated Learning. NY: Cambridge Univ. Press

Dalton-Puffe, Ch., Marsh, D. (2007). Discourse in Content and Language Integrated Learning Classrooms. Amsderdam: John Benjamins Publishing Company.

European Comission (LCEMG). (2012). "Language competences for employability, mobility and growth". Strasburg, SWD, Sci.rep. 372 final. Retrieved from: https://www.bath.ac.uk/publications/library-guides-to-citingreferencing/attachments/ieee-style-guide.pdf

Eurydice (CLILSE). (2006). "Content and Language Integrated Learning at School in Europe", Survey Eurydice European Unit. [Online]. Retrieved from: http://www.indire.it/lucabas/lkmw_file/eurydice/CLIL_EN.pdf (in English)

Forostiuk, I. (2017). Use of Moodle Platform in the Process of Teaching Foreign Languages at Non-Linguistic Higher Educational Institution. Naukovij Visnik Mizhnorodnogo Gumanitarnogo Universitetu, V. 3, № 3, 191-193.

Kern, N. (2013). Technology-integrated English for Specific Purposes lessons: real-life language, tasks, and tools for professionals. Innovations in learning technologies for English language teaching, 87-117

Kotova, A. (2015). Role of IT Technologies in the High School Educational Process Visnik Harkivskogo nacionalnogo universitetu imeni V. N. Karazina. Seriya «Valeologiya: suchasnist i majbutnye, № 978, 81-84

Kulik, O. (2019). Role of Information and Communication Technologies in the Educational Process in Higher Institutions. Zbirnyk naukovykh prats profesorsko-vykladatskoho skladu DonNU imeni Vasylia Stusa, T. 2, 75-77.

Kolos, K. (2011). Moodle system as a tool for the development of subject competencies of IT teachers under the conditions of distant postgraduate studies. Avtoref. dys. na zdobuttia nauk. stupenia kand. ped. nauk : spets. 13.00.10,Informatsiino-komunikatsiini tekhnolohii $v$ osviti, 21.

Lightbown, P., Spada, V. (1997). Learning English as a second language in a special school in Quebec. Canadian Modern Language Review, N. 53, 315-355.

Llinares, A., Whttaker, R. (2006). Linguistic Analysis of Secondary School Students oral and Written Production in CLIL Contexts: Studying Social Science in English. VIEWS, V. 15, 28-32

Long, M. (1991) Focus on form: A design feature in language teaching methodology. Foreign language research in cross-cultural perspective, 39-52. (in English) 
SOCIETY. INTEGRATION. EDUCATION

Proceedings of the International Scientific Conference. Volume I, May $28^{\text {th }}-29^{\text {th }}$, 2021. 316-326

Lukianenko, V. (2014). Experience of Implementing Distance Education for Organization of Students' self-work for Professional Purposes. Pedagogichnij Process: Teoriya $i$ Praktika, V. 2, 70-75.

Marsh, D., Nikula, T. (1998 ). Terminological Considerations regarding Content and Language Integrated Learning. Bulletin Suisse de Linguistique Appliquee, 13-18.

Ovtcharenko, Z. (2018). "Information technologies as a Way of English Language Study Intensification” [Online], 2018. Retrieved from: http:/www.kamts1.kpi.ua/sites/ default/files/files/ovcharenko_informatsiini.pdf (in Ukrainian)

Petruk, V. (2011). Problems in Socialisation and Individualisation of Educations under modern information and educational environment. Osvita i Upravlinnya, V. 14, N. 2-3, 86-94 